\title{
Analisis Materi dan Tujuan Pembelajaran pada Materi Listrik Dinamis
}

\author{
Rachmat Rizaldi ${ }^{1)}$, Syahlan ${ }^{1,{ }^{*}}$ \\ ${ }^{1)}$ Universitas Islam Sumatera Utara \\ *syahlan@fkip.uisu.ac.id
}

\begin{abstract}
Abstrak: Penelitian ini memberikan gambaran tentang sub-sub materi pada pokok bahasan listrik dinamis. Tujuan khusus penelitian ini adalah menganalisis materi dan tujuan pembelajaran tentang pembelajaran Fisika yang telah berlangsung di sekolah, meliputi persentase fakta, konsep, dan prinsip yang terdapat pada materi. Untuk tujuan pembelajaran dilihat dari persentase tingkatan Taksonomi Bloom. Materi dalam penelitian ini yang dianalisis adalah materi Fisika SMA kelas X tentang Listrik Dinamis. Berdasarkan hasil analisis materi diperoleh persentase jumlah fakta, konsep, prinsip, dan prosedur masing-masing 28\%, 30\%, 36\%, dan 6\%. Dari hasil persentase analisis materi terlihat bahwa yang mendominasi materi listrik dinamis adalah konsep dan prinsip. Anaisis materi yang ideal diperlukan dalam memahami fakta dan prinsip pada materi Fisika. Hal ini diharapkan supaya siswa dapat mencapai tujuan pembelajaran materi listrik dinamis dengan baik. Untuk analisis tujuan pembelajaran materi listrik dinamis terlihat bahwa tujuan pembelajaran sudah mencapai tingkatan C5 tetapi belum mencapai tingkatan C6 sesuai dengan target tujuan pembelajaran Fisika nasional. Oleh karena itu perlu adanya perbaikan dalam penyusunan materi Fisika pada pokok bahasan Listrik dinamis.
\end{abstract}

Kata Kunci: Analisis Materi, Materi pembelajaran Fisika, Listrik dinamis.

\section{Pendahuluan}

Proses pembelajaran merupakan interaksi yang terjadi antara guru dengan siswa dalam upaya untuk memperoleh dan memproses ilmu pengetahuan, keterampilan, dan sikap. Selama kegiatan belajar mengajar berlangsung terjadi proses komunikasi dua arah yaitu belajar yang dilakukan oleh siswa dan mengajar oleh guru. Belajar adalah suatu aktivitas yang dilakukan secara psikologis (berpikir, memahami, menyimpulkan, menyimak, menganalisis, dan sebagainya) maupun secara fisiologis (melakukan percobaan, praktik, latihan, apresiasi).

Salah satu upaya yang dilakukan dalam proses komunikasi adalah berupa pengajuan pertanyaanpertanyaan dan menjawab pertanyaan. Pertanyaan merupakan sembarang bentuk kalimat verbal dan nonverbal untuk mengkomunikasikan suatu pesan kepada seseorang sesuai tujuan-tujuan tertentu. Diantaranya tujuan tersebut digunakan untuk 1) meninjau, memeriksa, menyelidiki dan merangsang ide, proses berpikir dan pemahaman mereka, 2) mengajukan masalah, 3) mencari solusi alternatif, 4) mengembangkan sikap dan motivasi untuk terlibat dalam proses pembelajaran, 5) membangun pengetahuan dan mendorong untuk mengartikulasikan apa yang diketahui (Redhana, 2013; Balanay \& Roa, 2013; Redhana, 2014; Purnomo, 2016)(Balanay \& Roa, 2013). Pendapat tersebut searah dengan aliran konstruktivisme yang menyatakan bahwa belajar adalah menyusun pengetahuan dari pengalaman konkret, aktivitas kolaborasi, refleksi dan interprestasi. Jadi, proses belajar ini bersifat keseluruhan yang menitikberatkan pada pemahaman, berpikir kritis dan reorganisasi pengalaman. Melalui pengalaman yang diperoleh, siswa akan menginterprestasikan konsep-konsep yang relevan dengan apa yang hendak dipahaminya melalui suatu proses/aktivitas kolaborasi dan refleksi sehingga diperoleh suatu pemahaman yang baru.

Pembelajaran Fisika dalam kuikulum 2013 menuntut siswa selain dapat memahami materi dengan baik juga dapat mengembangkan keterampilan proses yang ada pada dirinya. Untuk dapat mengembangkan keterampilan proses dalam belajar perlu adanya aspek-aspek yang perlu diperhatikan dalam bahan ajar yang digunakan guru. Guru perlu melakukan analisis materi dan tujuan pembelajaran untuk memperoleh hasil yang diharapkan sesuai tuntutan dari kurikulum 2013. Permendikbud No. 69 tahun 2013 tentang Kurikulum SMA maupun MA menyatakan bahwa Kompetensi inti materi ini adalah meliputi pengetahuan faktual, konseptual, 
prosedural untuk dapat diterapkan dalam bidang teknologi, seni, budaya, dan humaniora sehingga mampu memecahkan masalah secara procedural pada bidang kajian yang spesifik sesuai dengan bakat dan minatnya (Pemerintah R.I., 2013).

Pengetahuan Prosedural adalah pengetahuan tentang tahapan yang harus dilakukan dalam melakukan suatu kajian misalnya dalam hal membuat besi menjadi magnet, singkatnya adalah tentang pengetahuan bagaimana. Pengetahuan prosedural adalah pengetahuan yang berkaitan dengan prosedur atau cara untuk melakukan sesuatu (knowing how to do something). Oleh karena itu pengetahuan prosedural ini terbagi atas: (1) pengetahuan tentang keterampilan dalam bidang tertentu dan algoritma; (2) pengetahuan tentang teknik dan metode dalam bidang tertentu; dan (3) pengetahuan tentang kriteria untuk menentukan kapan harus menggunakan prosedur yang tepat (Gunawan \& Paluti, 2012).

Dengan pencapaian kompetensi inti ini siswa dapat mengetahui bagaimana tahapan untuk memahami materi fisika dalam melakukan instalasi kelistrikan. Hal ini sesuai dengan pernyataan Hasanah dan Malik bahwa Profil kompetensi kerja bidang kelistrikan berdasarkan klasifikasi industri besar, dikelompokkan ke dalam enam kompetensi dasar (Hasanah \& Malik, 2015), yakni: 1) dasar-dasar kelistrikan; 2) dasar-dasar elektronika; 3) perawatan dan perbaikan peralatan-peralatan kelistrikan Industri; 4) pengoperasian tenaga listrik; 5) Manajemen kelistrikan; dan 6) keselamatan dan kesehatan kerja (K3).

Sedangkan pada kompetensi dasar materi Listrik dinamis adalah mengevaluasi prinsip kerja peralatan listrik searah (DC) dalam kehidupan sehari-hari dan melakukan percobaan untuk menyelidiki karakteristik rangkaian listrik. Adanya aktivitas dalam suatu pembelajaran sangat perlu ditekankan untuk membantu siswa memahami struktur atau ide-ide kunci suatu disiplin ilmu dan kebutuhan akan keterlibatan aktif siswa dalam proses belajar dan keyakinan bahwa pembelajaran sejati terjadi melalui penemuan. Dengan terlibat aktif siswa mampu mengenali, menjelaskan pokok bahasan listrik dinamis dengan baik. Jika peserta didik mampu mengenali, menjelaskan dan menginterpretasikan suatu masalah maka pemahaman peserta didik terhadap suatu materi akan dapat dioptimalkan. Adapun untuk evaluasi terhadap ruang lingkup materi kurikulum dilakukan dengan cara: a) meniadakan materi yang tidak esensial atau tidak relevan bagi siswa, b) mempertahankan materi yang sesuai dengan kebutuhan siswa, c) menambah materi yang dianggap penting dalam perbandingan internasional (Syahlan, 2016).

Penyusunan materi listrik dinamis dalam Kurikulum 2013 dilakukan dengan cara mengelompokkan materi kedalam fakta, konsep, prinsip, dan prosedur (Pemerintah R.I., 2013). Klasifikasi materi pembelajaran mencakup fakta, konsep, prinsip, dan prosedur. Pengelompokan ini akan mempermudah guru menyampaikan pokok bahasan pembelajaran sesuai tujuan pembelajaran. Untuk melihat tercapainya pokok bahasan dengan baik dilkukan dengan menglompokkan tujuan pembelajaran kedalam tingkatan taksonomi bloom yang terdiri dari C1 sampai tingkatan C6 (pengetahuan, pemahaman, penerapan, analisis, sintesis, dan evaluasi). Penjabaran materi dengan cara seperti ini dapat mengembangkan pengetahuan dan keterampilan siswa dalam bidang Fisika untuk mengidentifikasi, memahami, mengolah informasi dan membuat keputusan yang tepat dalam menyelesaikan masalah yang dapat dijumpai siswa dalam kehidupan sehari-harinya. Oleh karena itu penting dilakukan pembahasan tentang analisis materi dan tujuan pembelajaran Fisika untuk memperoleh kompetensi belajar peserta didik menjadi lebih baik.

\section{Metode}

Metode dalam penelitian ini adalah metode penelitian deskriptif. Subjek dalam penelitian adalah tujuan pembelajaran Fisika kelas X, yaitu pada materi Listrik Dinamis. Adapun objek dalam penelitian adalah untuk mengetahui materi-materi apa saja yang sesuai berdasarkan tujuan pembelajaran Fisika yang telah berlangsung di sekolah, meliputi persentase fakta, konsep, dan prinsip yang terdapat pada materi Listrik Dinamis serta persentase tingkatan materi sesuai Taksonomi Bloom.

Instrumen yang digunakan adalah lembar klasifikasi materi dan tujuan pembelajaran fisika yang meliputi persentase fakta, konsep, prinsip, dan prosedur. Untuk analisis data materi listrik dinamis yang digunakan diperoleh dari persentase jumlah fakta, konsep, prinsip. Sedangkan untuk analisis data tujuan pembelajaran diperoleh dari persentase jumlah fakta, konsep, prinsip, dan prosedur berdasarkan tingkatan taksonomi Bloom. 


\section{Hasil dan Pembahasan}

\section{Analisis Materi Listrik Dinamis}

Analisis materi listrik dinamis dilakukan dengan cara mengelompokkan materi kedalam fakta, konsep, prinsip, dan prosedur. Persentase hasil analisis materi yang diperoleh adalah fakta sebesar 28\%, konsep 30\%, dan prinsip 36\% dan prosedur 6\% (tabel 1). Dari hasil persentase analisis materi terlihat bahwa materi listrik dinamis yang mendominasi yaitu fakta, konsep dan prinsip. Dimana tingkatan kognitif materinya adalah 36\% pengetahuan (C1), 48\% pemahaman (C2), 6\% penerapan (C3), 2\% analisis (C4), dan $2 \%$ sintesis. Untuk tingkatan evaluasi (C6) tidak ada.

\section{Analisis Tujuan Pembelajaran Listrik Dinamis}

Untuk melihat tercapainya materi pembelajaran dengan baik dilakukan dengan mengelompokkan tujuan pembelajaran kedalam tingkatan taksonomi bloom yang terdiri dari C1 sampai tingkatan C6 (Form analisis tujuan pembelajaran terlampir). Hasil analisis tujuan pembelajaran dilihat dari persentase klasifikasi (tabel 2): fakta sebesar 27,27\%, konsep sebesar 18,18\%, prinsip 27,27\% dan prosedur sebesar 27,27\%. Sedangkan untuk tingkatan Taksonomi Bloom, persentase untuk tingkatan C1 adalah 4,54\%, C2 adalah 18,18\%, C3 adalah 27,27\%, C4 adalah 36,36\%, C5 adalah 13,64\%, dan C6 adalah 0\%. Untuk tujuan pembelajaran materi listrik dinamis terlihat bahwa tujuan pembelajaran sudah mencapai tingkatan C5 tetapi belum mencapai tingkatan C6 berdasarkan target tujuan pembelajaran Fisika nasional.

\section{Analisis Materi Listrik Dinamis}

Tahap analisis materi dilakukan identifikasi terhadap konsep esensial dari materi listrik dinamis. Analisis konsep dimaksudkan untuk mengidentifikasi konsep-konsep dalam pembelajaran sehingga dapat disusun sesuai urutan penyajian dan sistematis. Pemahaman konsep terkait dengan penyampaian informasi yang terkandung dalam suatu topik dengan skemata yang telah dimiliki sebelumnya. Hasil dari anlisis konsep ini dijabarkan pada perangkat pembelajaran Fisika yang dirancang. Analisis konsep juga disesuaikan dengan tuntutan kurikulum dan model pembelajaran yang akan diterapkan di kelas.

Hasil dari analisis materi yang telah dilakukan menjadi dasar dalam menentukan konsep-konsep utama pada pokok bahasan listrik dinamis. Untuk penerapan konsep-konsep dari materi listrik dinamis ini dapat dilakukan dengan langkah-langkah model pembelajaran sebagai contoh model inkuiri, dimana kegiatan pembelajaran ini digunakan untuk mengoptimalkan keterlaksanaan proses pembelajaran supaya dapat meningkatkan hasil belajar siswa baik pada kompetensi sikap, pengetahuan, maupun keterampilan. Hasil analisis materi listrik dinamis dapat terlihat dalam Tabel di bawah ini.

Tabel 1. Analisis Terhadap Materi Listrik Dinamis

\begin{tabular}{ccc}
\hline No & Klasifikasi & Materi (\%) \\
\hline 1 & Fakta & $28 \%$ \\
2 & Konsep & $30 \%$ \\
3 & Prinsip & $36 \%$ \\
4 & Prosedur & $6 \%$ \\
\hline
\end{tabular}

Berdasarkan Tabel di atas, diketahui bahwa materi ajar yang bersifat prosedur masih sedikit ditemukan pada materi listrik dinamis, padahal materi yang bersifat prosedur sangatlah penting pada pelajaran Fisika di Sekolah. Sebagaimana menurut NRC dalam (Asmida \& Nursangaji, 2016) bahwa kelancaran prosedural mengacu pada pengetahuan mengenai prosedur, pengetahuan mengenai kapan dan bagaimana menggunakannya secara tepat, dan keterampilan dalam melakukannya secara fleksibel, akurat, dan efisien.

Hasil penelitian (Purnomo, 2016) dapat diketahui bahwa walaupun peserta didik bisa melakukan prosedur matematika (kemampuan prosedural) akan tetapi tidak memiliki konsep yang ada dengan baik. Sebagaimana pernyataan (Arnidha, 2016) bahwa pengetahuan prosedural yang tidak didukung oleh pengetahuan konseptual akan menyebabkan siswa dapat memberikan jawaban dari soal tetapi tidak memahami apa yang mereka lakukan. Dengan demikian, dapat dikatakan bahwa materi yang bersifat fakta, konsep dan prinsip akan memberikan implementasi yang berbeda bagi peserta didik mengikuti kegiatan pembelajaran. Keterlibatan siswa pada kegiatan pembelajaran secara aktif dalam melakukan percobaan akan meningkatkan pemahaman siswa terhadap konsep dan prinsip fisika. Membantu siswa untuk memahami struktur atau ide-ide 
kunci suatu disiplin ilmu dan kebutuhan akan keterlibatan aktif siswa dalam proses belajar dan keyakinan bahwa pembelajaran sejati terjadi melalui penemuan. Oleh karena itu, (Khamidah, 2017) menyarankan kepada guru agar memberikan banyak latihan soal yang beragam jenis sehingga dapat membantu siswa dalam mengembangkan pengetahuan prosedural.

Untuk mendapatkan sub-sub pokok dan tujuan pembelajaran yang ideal pada materi listrik dinamis maka penting adanya analisis materi dan tujuan pembelajaran dalam pengajaran Fisika. Materi dengan klasifikasi fakta, konsep, prinsip, dan prosedur pada materi listrik dinamis didominasi konsep dan prinsip. Materi yang didominasi oleh konsep dan prinsip akan mampu meningkatkan keterampilan proses siswa. Tetapi materi yang bersifat fakta dan prosedur akan mampu membantu meningkatkan kemampuan pemecahan masalah.

Materi dengan klasifikasi prosedur akan membangun kemampuan prosedural siswa, sehingga mereka akan memiliki pengetahuan tentang criteria, yaitu kemampuan untuk menentukan kapan harus menggunakan prosedur yang tepat (Gunawan \& Paluti, 2012). Ilmu Pengetahuan ini dapat dijadikan contoh dalam pengetahuan kriteria untuk menentukan arus listrik DC dan AC serta alat apa yang sesuai untuk digunakan dalam mengukur arus listrik tersebut.

\section{Analisis Tujuan Pembelajaran Listrik Dinamis}

Tahap analisis tujuan pembelajaran pokok bahasan listrik dinamis dilakukan dengan pengelompokkan materi kedalam tingkatan taksonomi bloom. Hasil analisis tujuan pembelajaran listrik dinamis digambarkan pada tabel 2 .

Tabel 2. Analisis Terhadap Tujuan Pembelajaran Listrik Dinamis

\begin{tabular}{|c|c|c|c|c|c|c|c|c|}
\hline \multirow{2}{*}{ No } & \multirow{2}{*}{ Klasifikasi } & \multirow{2}{*}{ Materi (\%) } & \multicolumn{6}{|c|}{ Tujuan pembelajaran dari Tingkatan Kemampuan(\%) } \\
\hline & & & C1 & $\mathrm{C} 2$ & C3 & $\mathrm{C} 4$ & C5 & C6 \\
\hline 1 & Fakta & 27,27 & \multirow{4}{*}{4,54} & \multirow{4}{*}{18,18} & \multirow{4}{*}{27,27} & \multirow{4}{*}{36,36} & \multirow{4}{*}{13,64} & \multirow{4}{*}{0} \\
\hline 2 & Konsep & 18,18 & & & & & & \\
\hline 3 & Prinsip & 27,27 & & & & & & \\
\hline 4 & Prosedur & 27,27 & & & & & & \\
\hline
\end{tabular}

Pada tabel 2 memperlihatkan bahwa tujuan pembelajaran yang sudah dikembangkan di sekolah masih mencapai tingkatan C4, namun masih sedikit yang mencapai tingkatan C5 dan C6 yaitu 13,64\% saja. Ini menunjukkan bahwa tujuan pembelajaran fisika belum terpenuhi, seharusnya tujuan pembelajaran pada tingkat SMA/MA, minimal berada pada tingkatan C4, sebagaimana bunyi kompetensi inti pembelajaran fisika SMA, yaitu mengolah, menalar, dan menyaji dalam ranah konkret dan ranah abstrak terkait dengan pengembangan dari yang dipelajarinya di sekolah secara mandiri, dan mampu menggunakan metoda sesuai kaidah keilmuan.

Tingkatan mulai C5 dan C6 membutuhkan kreativitas dan keterampilan proses siswa, sehingga dibutuhkan latihan untuk menstimulus keterampilan proses yang lebih baik lagi. Keterampilan proses akan mampu membantu peserta didik menemukan konsep dan memecahkan suatu permasalahan. Lanjut (Balanay \& Roa, 2013), bahwa keterampilan proses diantaranya dapat mengembangkan kemampuan siswa dalam penyelidikan, investigasi, berhipotesis dan pemahaman.

Selain itu, persentase klasifikasi materi dan tujuan pembelajaran pada materi listrik dinamis belum proporsional. Oleh karena itu, perlu diperbaiki lagi agar dapat memenuhi tujuan pembelajaran fisika. Misalkan saja, untuk persentase klasifikasi materi baik fakta, konsep, prinsip dan prosedur, masing-masing sebesar 25\%. Sedangkan persentase tujuan pembelajaran fisika untuk setiap tingkatan kognitif lebih diperbanyak pada tingkatan C4 (sekitar 50\% - 60\%) dan selebihnya dialokasikan untuk tingkatan C5 dan C6. Kemampuan prosedural berada pada tingkatan kemampuan tinggi (C4 dan C5), yaitu kemampuan untuk menyelesaikan permasalahan-permasalahan semi-abstrak. Oleh karenanya dibutuhkan kemampuan kognitif yang baik.

\section{Simpulan}

Berdasarkan uraian pembahasan di atas, maka disimpulkan beberapa hal yaitu: 1) Hasil analisis materi diperoleh persentase jumlah fakta sebesar 28\% konsep 30\%, prinsip 36\% dan prosedur $6 \%$. Dari hasil persentase analisis materi terlihat bahwa yang mendominasi pada materi listrik dinamis adalah konsep dan prinsip; 2) Hasil 
analisis tujuan pembelajaran dilihat dari persentase tingkatan Taksonomi Bloom adalah sebagai berikut: tingkatan untuk C1 adalah 4,54\%, C2 adalah 18,18\%, C3 adalah 27,27\%, C4 adalah 36,36\%, C5 adalah 13,64\%, dan C6 adalah 0\%.

\section{Daftar Pustaka}

Arnidha, Y. (2016). Analisis Kemampuan Pengetahuan Konseptual Dan Prosedural Siswa SD dalam Pokok Bahasan Pecahan. 2(1), 54-60.

Asmida, S., \& Nursangaji, A. (2016). Pemahaman Konseptual dan Kelancaran Prosedural Siswa dalam Operasi Hitung Bilangan Bulat di Sekolah Menengah Pertama. Jurnal Pendidikan Dan Pembelajaran, 5(6), 1-14.

Balanay, C. A. S., \& Roa, E. C. (2013). Assessment on Student s' Science Process Skills : A Student-Centred Approach. International Journal of Biological Education, 3(1), 24-44.

Gunawan, I., \& Paluti, A. R. (2012). Taksonomi Bloom - Revisi Ranah Kognitif: Kerangka Landasan Untuk Pembelajaran, Pengajaran, dan Penilaian. Jurnal Pendidikan Dasar Dan Pembelajaran (Premiere Epicandum), Vol. 2 (2): 98 - 117., 2(2), 98-117.

Hasanah, \& Malik, M. N. (2015). Profil Kompetensi Kelistrikan Berdasarkan Klasifikasi Dan Kualifikasi Industri Untuk Pengembangan Pendidikan Dan Latihan Kejuruan. Jurnal Cakrawala Pendidikan, 34(1), 78-88. https://doi.org/10.21831/cp.v1i1.4178

Khamidah, L. (2017). Pemahaman Konseptual Dan Pengetahuan Prosedural Siswa Kelas VIII Dalam Penyelesaian Soal Matematika Pada Materi Sistem Persamaan Linier Dua Variabel. Prosiding SI MaNis (Seminar Nasional Integrasi Matematika Dan Nilai Islami, 1(1), 611-616.

Pemerintah R.I. (2013). Peraturan Menteri Pendidikan dan Kebudayaan Republik Indonesia Nomor 69 tahun 2013 tentang Kerangka Dasar dan Struktur Kurikulum Sekolah Menengah Atas/Madrasah Aliyah. 2013-2015.

Purnomo, Y. W. (2016). The Instructional Improvement In The Implementation Of Assessment Based Learning In Mathematics Class. Cakrawala Pendidikan, 35(3), 403-411.

Redhana, I. W. (2013). Model Pembelajaran Berbasis Masalah Dan Pertanyaan Socratik Untuk Meningkatkan Keterampilan Berpikir Kritis Siswa. Jurnal Cakrawala Pendidikan, 3, 351-365. https://doi.org/10.21831/cp.v0i3.1136

Syahlan. (2016). Literasi Matematika Dalam Kurikulum 2013. Keguruan: Jurnal Penelitian, Pemikiran Dan Pengabdian, 3(1), 36-43. https://doi.org/10.31227/osf.io/cbsn5 